Copyright (C) 2021 by Cherkas Global University

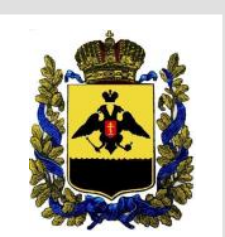

Published in the USA

Bylye Gody

Has been issued since 2006.

E-ISSN: $2310-0028$

2021. 16(4): 1583-1593

DOI: $10.13187 /$ bg.2021.4.1583

Journal homepage:

https://bg.cherkasgu.press

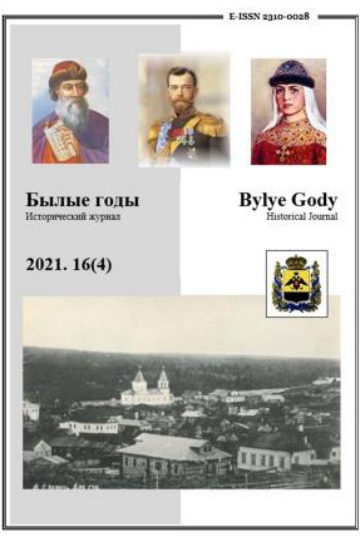

ARTICLES

\title{
The Polish-Lithuanian Power and Orthodox Rus as Portrayed in the Works of Polemicists at the end of the 16th - first third of the 17th centuries
}

\author{
Yulia A. Chupryna a , * \\ a St. Petersburg State University, Russian Federation
}

\begin{abstract}
This paper concerns the construction of the image of Polish-Lithuanian power in the context of religious polemics at the turn of the 16th -17 th centuries. Debates between Orthodox and Uniate Christians in the Polish-Lithuanian Commonwealth generated polemical texts which were created in the context of Orthodoxy's struggle for rights and freedoms. In the 19th and 20th centuries, polemical literature as an historical source was viewed through the prism of a national project or through a preexisting national narrative. When researching the relationship between Ukraine and Russia, historians found evidence in the polemical writing of the 17th century to justify oppression, explain distinctive culture, and account for national struggle. Contemporary historiography, however, offers new angles through which to view these texts, through the lens of intellectual history and memory studies. In this vein the historical worldview of a 17th century person becomes especially interesting.

At the center of our study are the views of Orthodox polemicists, who represent the "Ruthenian" populace in the Polish-Lithuanian Commonwealth, concerning the history of the rule of Lithuanian princes and Polish kings. The acceptance of the Union of Brest caused greater interest and reflection in this population to "one's own" past, legal situation, loyalty to the king; as a result, the image of Polish and Lithuanian rulers became more complicated. Aiming to legalize Orthodoxy, church leaders actualized historical images of princes and kings, presenting them as givers and guarantors of the rights and freedoms of Rus. Fighters for Orthodoxy were not repulsed by the fact that the king was Catholic; rather, they agitated for equality between the Greek and Roman faiths. We find justification for this equality given through an appeal to a glorious past, to the history of the annexation of Rus' lands to Lithuania, the Union of Lublin, and the granting of privileges by the Polish king.
\end{abstract} Union.

Keywords: Orthodox polemicists, image of power, the Polish-Lithuanian Commonwealth, Rus, Brest

\section{1. Введение}

Историческое мировоззрение человека раннего Нового времени в наши дни все чаще и чаще обсуждается в рамках международных конференций и форумов, на страницах научных исследований и научно-популярных проектов. Особенную актуальность этот вопрос получил на рубеже XX-XXI вв. на постсоветском пространстве. Исследователи стремятся определить роль исторического наследия в XVIXVII вв.: обращаются к этноконфессиональным проблемам, вопросам идентичности, нациестроительства, «местам памяти», образам «своего»/«чужого». Весьма актуальны и остры эти вопросы в связи с судьбами русского» населения Речи Посполитой XVI-XVII вв. после принятия Брестской унии 1596 г. Это время для

${ }^{*}$ Corresponding author

E-mail addresses: chupryna.yulya@mail.ru (Yu.A. Chupryna) 
православной церкви проходило под эгидой оживленной полемики с униатами. Конец XVI - начало XVII веков можно назвать рубежным моментом для православного русского народа, когда перед ним встали новые вызовы: раскол церкви, попытки осмысления своей общности, поиск своего места в новых условиях существования, борьба за свои права и т.д.

Православная полемическая литература стала ответом на унию, в ней отразились не только идейные искания и религиозные споры, но и историческое мировоззрение, которое претерпевало определенную ломку в связи с унией. Если образы древнерусской истории (князя Владимира, княгини Ольги, крещения Руси) затрагиваются в историографии, то восприятию польско-литовской власти и истории ВКЛ в контексте антиуниатской полемики почти не уделяется должного внимания. Однако, исключая обозначенный аспект, мы ограниваем историческое мировоззрение православных духовных деятелей Речи Посполитой. Таким образом, в центре внимания данного исследования находятся взгляды церковных деятелей «руского» народа на польско-литовскую власть, на историю правления литовских князей и польских королей.

\section{2. Материалы и методы}

Источниками нашего исследования стали труды православных полемистов конца XVI - первой трети XVII веков. Наиболее обширными и информативными источниками можно назвать «Апокрисис» Христофора Филалета, «Перестрогу» анонимного автора, «Obrona Verificaciey» Мелетия Смотрицкого, «Палинодию» Захарии Коспыстенского, «Synopsis» и «Supplementum Synopsis» виленских братчиков. Большинство источников было издано Киевской археографической комиссией в «Архиве Юго-Западной России» (АЮЗР, 1887; АЮЗР, 1914), Петербургской археографической комиссией в «Актах, относящихся к истории Западной России» (АЗР, 1851) и в «Русской исторической библиотеке, издаваемой Археографической комиссией» (РИБ, 1878; РИБ, 1882). Отдельно П.Н. Жуковичем была опубликована «Протестация» Иова Борецкого (Протестация, 1909).

В основу изучения исторических взглядов, распространенных в церковной элите, были положены общенаучные методы исследования: историко-критический, сравнительно-исторический, проблемно-хронологический. В работе анализируются, сравниваются и обобщаются упоминания православных церковных деятелей рубежа XVI-XVII вв. об исторических событиях, связанных с польско-литовской властью и историей Великого княжества Литовского. Также в исследовании прослеживается хронологическое развитие исторических образов от момента принятия Брестской унии до легализации православия в Речи Посполитой. Кроме того, особое значение имеет имагология, которая подразумевает анализ восприятия «своего» и «чужого» - в данном случае восприятия образа «своего»/«чужого» правителя и «своего прошлого» в контексте антиуниатской полемики.

\section{3. Обсуждение}

Рубеж XVI-XVII вв. связан с серьезными изменениями в положении православного населения Речи Посполитой. В государстве вводится уния, запрещается православие, а следовательно, усиливается интерес к «своему» прошлому, настоящему и будущему, встает вопрос правового положения и лояльности к правителю. Полемика по поводу Брестской унии велась церковными деятелями с обеих сторон на страницах печатных книг, получивших в историографии обобщающее название «полемическая литература». Она имела хождение в основном в интеллектуальной читающей среде, заинтересованной в изучении работ своих соратников и оппонентов.

Полемическая литература как источник использовалась историками чаще всего в качестве вспомогательного материала для подтверждения уже имеющейся концепции характера взаимоотношений малороссов с поляками. Так, в XIX столетии - веке рождения русского национализма - полемическая литература изучалась в контексте обоснования права Российской империи на земли Малороссии и Западного края (Барсук, 2014). Общерусский национальный проект включал в себя малороссийский и белорусский народы (Миллер, 2000), поэтому Брестская уния не могла рассматриваться положительно российскими историками. Православная полемическая литература использовалась для доказательства угнетения православных со стороны поляков. Именно благодаря росту национального самосознания, значительная часть полемической литературы оказалась изданной археографическими комиссиями Российской империи к концу XIX века (АЗР, 1851; РИБ, 1878; РИБ, 1882; АЮЗР, 1887; РИБ, 1903; Студинський, 1906; Протестация, 1909). К полемической литературе обратились авторы «Словаря исторического о бывших в России писателях духовного чина греко-российской церкви» (Словарь исторический, 1827а; Словарь исторический, $1827 \mathrm{~b}$ ), кратко характеризуя церковных деятелей и их печатные труды. О судьбах малороссийского народа писали такие историки, как Н.Н. Бантыш-Каменский (Бантыш-Каменский, 1830), М.О. Коялович (Коялович, 1863; Коялович, 1864), Н.И. Костомаров (Костомаров, 1888), В.З. Завитневич (Завитневич, 1883), П.Н. Жукович (Жукович, 1901), Н.А. Скабаланович (Скабаланович, 1873), И.П. Житецкий (Житецкий, 1890) и др.

В начале XX века интерес к этим источникам проявили уже украинские и белорусские исследователи, внесшие вклад в зарождение «своих» историографий и национализмов. 
Они рассматривали униатство как проявление самобытности народа (Барсук, 2014). В данном случае стоит обратить внимание на работы М. Довнар-Запольского, В. Ластовского, А. Станкевича, В. Игнатовского и др. Вспомним и труд М.С. Грушевского «История украинской литературы» (Грушевський, 1995; Грушевський, 1996) в шести томах. Польские же историки излагали обстоятельства унии пропольски (П. Бобровский, Я.Ярошевич, 3.Я. ДоленгаХодаковский и др.), что опять же отражает национальную повестку рубежа XIX-XX вв. строительство польского национального проекта «Польска - от можа и до можа».

В XX веке в работах советских и польских историков дискуссия продолжалась, лишь приобретая новые оттенки в рамках новой идеологии. Прогрессивность, как отмечает С.В. Савченко, связывалась с работами православных деятелей, а реакционность - с униатами и католиками. Богословская литература была необходима для изучения социальных проблем (Савченко, 2007: 162). Однако можно отметить труды В.Н. Перетца (Перетц, 1962), А. Белецкого (Білецький, 1963; Білецький, 1965), И. Еремина (Еремин, 1946).

На рубеже XX-XXI веков исследователи в основном отошли от оценочных характеристик и транслирования взгляда одной из сторон как верной или предпочтительной. Полемическая литература все чаще оказывается в центре внимания как источник в работах о ментальности, национальном самосознании, этничности, памяти, она продолжает использоваться в контексте построения национального нарратива. Кроме того, возобновилось издание и переиздание некоторых трудов полемической литературы, сборники выходили в США (Frick, 1987; Lev Krevza’s..., 1995; Frick, 2005), где особое внимание уделяется полемике М. Смотрицкого, Л. Кревзы и 3. Копыстенского. К нашему времени относится творчество достаточно крупных исследователей как за рубежом, так и на постсоветском пространстве. В частности, американская историография пополнилась работами И.И. Шевченко, Д. Фрика, С.Н. Плохия, Ф. Сисина, польская - трудами Т. Хинчевска-Хеннель, Я. Страдомского, Т. Ходаны. В контексте конструирования образов представляет особый интерес исследование Томаша Ходаны (Hodana, 2008), поскольку им предпринимается попытка примирения разных историографических школ и направлений. В отечественной историографии стоит отметить работы Б.Н. Флори, М. Дмитриева, О.Б. Неменского и их учеников, в украинской и белорусской историографиях - Н.Н. Яковенко, Н.А. Синкевича, С.В. Савченко, С. Сеника, И. Бортника, В.Г. Короткого. Названные историки в разной степени обращаются к этноконфессиональным вопросам и к историческим взглядам полемистов. Не менее значимы результаты и международных конференций в рамках проекта «Восточные славяне в поисках новых надрегиональных идентичностей в конце XV - середине XVIII в. в контексте зарождения модерных наций в Европе» (Доронин, 2017; Доронин, 2018; Доронин, 2019; Доронин, 2020). Данный проект объединил исследователей из Белоруссии, Украины, России, Польши и Литвы. Вопросы конструирования «своего прошлого» относятся к магистральным темам дискуссий конференций.

\section{4. Результаты}

Конструирование «своего прошлого» православными духовными лицами Речи Посполитой было вызвано принятием Брестской унии. Она вступала в противоречие с восприятием «руским» народом своего места в государстве, вызывала недовольство из-за ограничения прав и свобод по причине вероисповедания. Это было связано с решением польского короля подтвердить передачу униатам прав и привилегий, которые ранее принадлежали православной церкви. По сути, нарушалось религиозное равновесие, установленное благодаря Генриховым артикулам (1573), акту Варшавской Конфедерации (1573) и более ранним привилегиям, полученным от польско-литовских правителей во время присоединения земель Руси. Именно поэтому вопрос положения православных в Речи Посполитой для полемистов стал принципиальным. В этой связи особую роль играет образ власти, ведь именно монарх наделяет народ правами или же ограничивает их. В критический момент обычно происходит изменение в восприятии образа государя, он получает новые интерпретации, его образ актуализируется и конструируется более отчетливо и с определенной оптикой.

Несомненно, богатый материал для изучения обозначенной проблематики дают старые хроники и летописи, воспринятые духовной православной средой XVII века. Необходимо понять, что полемическая публицистика - это результат кропотливой работы по отбору, переработке, анализу и компиляции уже имеющихся исторических концептов и образов, что, конечно, не умаляет значимости полемических трудов как образцов конструирования «своего прошлого».

Началом полемики о необходимости заключения унии можно считать еще 1577 год, когда иезуит Петр Скарга написал книгу «О единстве церкви божией под властью единого пастыря» (Барсук, 2014: 13). Появление такого произведения после Люблинской унии вполне логично: многим тогда казалось, что после политического объединения необходимо объединение религиозное. Ответ с православной стороны последовал не сразу, да и первые работы были скромными - анонимные произведения «Послания до латин из их же книг» (1582) и «На богомерзкую, на поганую латину» (1582). Далее дискуссия набирает обороты.

Обращаясь к ранней полемике конца XVI века - к анонимным работам (Послание до латин, 1903) и трудам Герасима Смотрицкого (Ключ Царства, 1887), Стефана Зизании (Казанье святого 
Кирилла, 1906) - можно отметить некоторые особенности. Дело в том, что сначала православные полемисты редко затрагивали образ литовского князя или польского короля, а в каких-то случаях и вовсе не проявляли интереса к аспекту подданства, увлекаясь религиозными догматами и историей церкви. Подобная ситуация наблюдается и у сторонников унии, где упоминания о польских королях тоже немногочисленны. К этой категории памятников можно отнести следующие работы: «Ключ Царства Небесного» (1587), «О единой истинной православной вере» (1588), «Ответ клирика острожского Ипатию Потию» (1598), «Вопросы и ответы православному с папежником» (16о3), «Ектезис» (1597), «История о разбойничьем флорентийском соборе» (1598). Сюжетная взаимосвязь вполне естественна, т.к. полемический труд предполагает, что оппонент прочтет текст и ответит на него, а следовательно, круг заданных тем ограничен самим собеседником. Конечно, полемист может не следовать тексту своего оппонента, а приводить новые аргументы, но привлечение исторических событий и светских персон для доказательства своей точки зрения будет позже. Именно поэтому в полемических трудах отчетливо наблюдается постепенное расширение использованных аргументов, источников и апелляции к историческим событиям и правителям.

В конце XVI - начале XVII вв. упоминания сводились в основном к нескольким фигурам: Сигизмунда II, Генриха III Валуа, Стефана Батория и Сигизмунда III. Они возникали в контексте дарования или подтверждения прав и свобод для «руского» населения Речи Посполитой. Так, «Апокрисис» Христофора Филалета (1597-1599) и «Антиграфи» Мелетия Смотрицкого (1608) дают нам многочисленные обращения к польским королям. В «Апокрисисе» Сигизмунд II Август упоминается в контексте получения привилегий Волынскими и Киевскими землями, когда те «шли под руку» польского короля (имеется в виду Люблинская уния). В привилегиях гарантировалось, что православная религия не будет ущемляться и уничтожаться - эти гарантии даны на Люблинском сейме, (Апокрисис, 1882: 554), также король подтверждал уже имеющиеся права «Руси» (Апокрисис, 1882: 565). Генриха III Валуа связывают с присягой над артикулами (Апокрисис, 1882: 558), а Стефан Баторий упоминается в связи с королевскими привилегиями 1581, 1584, 1585, 1586 гг. (Апокрисис, 1882: 569-574). Мелетий Смотрицкий в «Антиграфи» приводил обширные выдержки из королевских грамот о введении нового календаря, упоминая Стефана Батория (Антиграфи, 1903: 607-6о8). А польский король Сигизмунд III актуализируется, конечно, как действующий правитель, который занимается правовыми проблемами.

Светская власть, как и позиция самого короля, выступают как бы на заднем плане, сам он присутствует в кратких упоминаниях. Князь или король не выступает центральной фигурой, деяния которого вызывают интерес, но зримо, а иногда и незримо присутствует при дарении и гаранте всех привилегий. На начальном этапе полемики для доказательства своей правоты полемисты обращались к относительно поздней истории, к времени польско-литовских королей XVI столетия, причем именно в контексте дарования и подтверждения прав «руского» народа греческой религии. Это и неудивительно, т.к. на тот момент правовой статус православного «руского» народа являлся самым важным. Далее риторика изменится не очень значительно, добавятся лишь новые события, имена королей и князей. Круг вопросов до 1632 года по-прежнему ограничивался тематикой прав и свобод, а упоминания о правителе служили подтверждением и гарантом законности положения православных.

Тем не менее интересные замечания мы находим в антиуниатском труде «Перестрога» (1605), в котором речь идет о более ранней историй, связанной с образованием государства и политикой польских и литовских князей. Анонимный автор «Перестроги» объяснял присоединение Руси к польским и литовским землям скорее как присоединение хитростью: литовцы и поляки помогали князьям Руси бороться друг с другом, а потом, воспользовавшись ослабленным положением Руси изза междоусобных войн, покорили их (Перестрога, 1851: 204). Здесь представлен неоднозначный взгляд на литовскую и польскую власть. Несколько иной взгляд на эти древние события представлен в более позднем труде 3. Коспыстенского «Палинодия» (1621). Он тоже упоминал о междоусобицах «руских» князей, об ослаблении княжеств, о помощи польских королей. Однако присоединение к Польше или Литве происходило на добровольной основе по причине ослабленного положения Руси и желания спастись от «поганского ярма» (Палинодия, 1878: 492). Процесс присоединения мог пониматься по-разному, но в целом в полемике не звучат идеи об угнетении и порабощении польской властью, которые выдвигала историография XIX-XX вв.

На 20-е годы XVII века приходится пик полемики. Мелетий Смотрицкий в числе первых заговорил о древней истории, когда Русь существовала отдельно от Великого княжества Литовского. Он обратил внимание оппонентов на то, что права русскому народу даны задолго до польсколитовских правителей. В «Obrona Verificaciey» (1621) полемист заявил, что светские письменные права даны еще при древнерусских князьях Владимире и Ярославе. Затем, вступив в ПольскоЛитовское государство, Русь получила все те же права и свободы, что и литовцы, и поляки (Obrona Verificaciey, 1887: 392). Образы Владимира и Ярослава Мудрого имели большую популярность в 1620-1630-е годы в православной среде, в том числе благодаря «Палинодии» 3. Копыстенского, «Synopsis» и «Supplementum Synopsis» (1632). Нужно признать, что эти исторические образы интересовали и сторонников унии, которые не раз апеллировали к Владимиру и Ярославу (Савченко, 2007: 126). 
Постепенно аргументация полемистов наполняется новыми историческими деталями, связанными с периодом Древней Руси, временем раздробленности и затем объединения с ВКЛ. Происходит более глубокое осмысление «своего» прошлого. Полемисты оперируют доступным материалом из хроник Й. Бельского, М. Кромера, М. Стрыйковского, воспроизводя отдельные фрагменты из их работ (Дернович, 2018: 81). В западнорусских землях наибольшее распространение получило краковское издание 1611 года «Kronika sarmacji europejskiej» А. Гваньини на польском языке, которое стало источником для кириллических изданий (Дернович, 2018: 81).

Возвращаясь к полемическим сочинениям и историческим взглядам, в них отразившимся, отметим, что деятели православной церкви не уделяют значительного внимания Люблинской унии. Четких разграничений между ВКЛ и Речью Посполитой не прослеживается, в том смысле, что полемисты не разделяют историю на «до» и «после» образования Речи Посполитой, хотя, конечно, они знают об этом событии, отличают литовских князей и польских правителей. Однако история в их представлении скорее плавно течет своим чередом, т.е. продолжается постепенное развитие «старины». Люблинская уния мыслится как очередной этап подтверждения прав Руси. Так, в «Палинодии» Захарии Копыстенского говорится, что Жигимонт (Сигизмунд) Август в 1569 году объединил княжество Литовское, Киев и Волынь с Польским королевством. При этом права и свободы сохраняются для представителей римской и греческой религий, а тяготы, оборона государства и сам король теперь становятся общими для Польши, Руси и Литвы (Палинодия, 1878: 531-532). Этот же вопрос затрагивается в «Synopsis» 1632 года (Synopsis, 1887: 546-547), где тоже заявляется о равных правах и вольностях. В более позднем труде Афанасия Филипповича «Диариуш» (1646) о Люблинской унии есть схожая запись о том, что Сигизмунд II Август привел Волынские и Киевские земли к польской короне и обещал сохранять права православных (Диариуш, 1878: 73). Риторика в отношении Люблинской унии, как можно заметить, за 20 лет не сильно изменилась. Полемистов намного больше интересует Брестская уния, которая повлияла на привычный порядок вещей, в то время как Люблинская уния, во всяком случае по их мнению, не сказалась на положении православия.

Вновь встречаем упоминания о польских королях в трудах М. Смотрицкого, который значительно расширил поле исторических персонажей, причем во многом за счет обращения к Кромеру и Стрыйковскому. У Смотрицкого мы наблюдаем апелляцию к древнерусским, литовским и польским правителям - это Ярослав, Изяслав, Ольгерд (вместе с его двумя женами и историей принятия христианства), Ягайло, Витовт, Мешко I, Болеслав, Казимир II, короли XVI столетия и т.д. В целом делается два акцента: либо правитель как-то был связан с христианством греческого образца (крестился, поощрял строительство храмов), либо правитель дарует привилегии православному народу. $\mathrm{B}$ «Палинодии» 3. Копыстенского, где исторические подробности тоже берутся из работ Кромера и Стрыйковского, мы наблюдаем обилие отсылок к правителям: Болеславу III Кривоустому, Ольгерду, Ягайло, Ядвиге, Казимиру II, Казимиру III, Казимиру IV, Стефану Батории, Сигизмунду I, Сигизмунду II, Сигизмунду III и многим другим, т.е. все те же фигуры, что и в работах М. Смотрицкого.

Белорусский историк В.А. Воронин отмечает, что в это время были особенно важны как «места памяти» Витовт и Ольгерд: Витовт как герой Литвы - могущественный правитель, полководец, креститель Литвы и Ольгерд как герой Руси - крупный полководец, государственный деятель, принявший православие (Воронин, 2019). Что касается Витовта, то православные церковные деятели в своих трудах не уделяли особого внимания его деяниям, даже несмотря на то, что князь один раз был крещен в православие. Ольгерд как поборник православия вызывал больше интереса и симпатий, поэтому в нарративе его образ дополняется событиями прошлого.

Все названные исторические личности, конечно, в разной степени освещены в текстах: кто-то лишь упомянут без излишних пояснений, а кто-то выступает благодетелем православия. О чем может говорить такое обилие имен? Помимо того, что полемисты просто активно работали с историческими сочинениями, мы можем предположить, что они все чаще актуализировали не только древнерусских персонажей (Ольгу, Владимира, Ярослава) и польских королей XVI столетия, но и проявили значительный интерес к ранним литовским и польским князьям и королям, к судьбе Руси в составе ВКЛ.

Еще одним важным источником является «Synopsis» 1632 года и дополнение к нему «Supplementum Synopsis», подготовленные виленскими братчиками на сейм того же года. В этих трудах делался упор на исторические факты, доказывающие право на православную веру и наличие равных прав и свобод для участия в управлении Польско-Литовским государством. Здесь важно заметить, что одновременно с этим происходила еще большая актуализация исторических образов правителей ВКЛ и Речи Посполитой, которые выступали дарителями и гарантами прав и свобод для православного населения. Они утверждали, что права, свободы, вольности, привилегии были даны с 980 по 1510 г. народу «рускому». Их дали князья Владимир, Ярослав Владимирович, Мечислав (Мешко III Старый), король польский Казимир III, князь литовский и король польский Ягайло (Владислав II Ягелло), король польский и венгерский Владислав III Ягеллович, князь литовский и король польский Александр Казимирович и т.д. (Synopsis, 1887: 543) В «Synopsis» наблюдается уже знакомая схема апелляции к правителям. Так, под 1340 годом фигурирует запись о присоединении земель. Описывается, как Казимир III захватил Львов, но обещал сохранить православную веру и не чинить православию злодеяний (Synopsis, 1887: 540). Далее в «Synopsis» актуализируется 
исторический образ литовского князя Ягайло, который заключил Кревскую унию. После католического крещения и женитьбы на Ядвиге он становится польским королем под именем Владислав II Ягелло. Братчики, вспоминая об этом, акцентируют внимание на том, что вместе с князем крестились его советники и братья, но не «руский» народ. Они остались в подчинении патриарха, а Владислав II запретил людям латинской веры вступать в браки с православными, чтобы они не отошли от римской церкви (Synopsis, 1887: 541).

Таким образом, присоединение земель к Литве и Польше подразумевало закрепление прав православного народа, который должен был стать равноправной частью Речи Посполитой. Эти взгляды, по сути, говорят нам о характере понимания одного из аспектов подданства, т.е. отношения с властью - они выстраивались на основе дарения и подтверждения прав. Конечно, обоснование равенства делалось не только на основе прав, но и на основе апелляции к воинской доблести «руского» народа в настоящем (Неменский, 2013) и к славному историческому прошлому Руси до присоединения к Великому княжеству Литовскому и Речи Посполитой.

Однако, как было сказано выше, православное население было недовольно ограничением своих прав. И здесь встает вопрос, как это могло отразиться на проявлении лояльности к «своему» правителю? А следовательно, можно ли говорить о негативном образе? С одной стороны, интересно, что в первой половине XVII века православное духовенство еще продолжало проявлять лояльность по отношению к польскому правительству, даже в условиях религиозной борьбы с униатством. Мы не находим призывов к отделению от Речи Посполитой в полемических трудах, хотя католики обвиняются во всех бедах православной церкви: упадке образованности, отходе знатных родов от православия (Тренос, 1995: 313), но это не касается королевской власти. До середины XVII века альтернативные идеи не обсуждались среди православных интеллектуалов, хотя, как отмечает О.Б. Неменский, впервые идея о присоединении к Москве высказана посольством из Малой Руси уже в 1620-е годы (Неменский, 2013: 294), но дальнейшего развития не получила.

С другой стороны, сложность и неоднозначность этого вопроса обусловлена актуализацией образа Московского царства в православной западнорусской элите и появлением альтернативы в лице «праведного» московского царя. Апелляция к своему соседу началась не сразу, а в первой половине XVII в. Наибольший интерес проявляли Иван Вишенский, Иов Борецкий, Захария Копыстенский. В этом плане можно согласиться с такими историками, как М.В. Дмитриев (Дмитриев, 2008), С.М. Савченко (Савченко, 2006: 21-32), Е.В. Русина (Русина, 2008), Т. Ходана (Ноdana, 2008: 102), которые считают, что актуализация образа Москвы как благочестивого государства произошла именно в XVII веке. Ведь ранее просто не вставало острой необходимости осмысления себя и своей общности, культуры, истории. После принятия Брестской унии обстоятельства изменились, православным интеллектуалам пришлось обратиться к своему соседу. Это было спровоцировано политикой, которую проводили польские короли.

\section{5. Заключение}

Однако, несмотря на трудности, которые испытывали религия и церковь, мы не наблюдаем в домогилянской полемической литературе мыслей и призывов к объединению с Московским царством. Да, в его главе видели защитника православия, благотворителя, праведного царя и авторитет его был велик. Но польско-литовские князья и короли предстают дарителями прав и свобод, в них видели гарантов правового положения православной Руси. Эти правители воспринимались как свои собственные, и законность власти польского короля не подвергалась сомнению. Русинское население считало себя полноценной частью ВКЛ, а затем и Речи Посполитой, подданными короля, так как их права постоянно подтверждались на коронациях и были уравнены с правами других народов. Вот почему православное духовенство пыталось решить проблемные вопросы на сеймах и с королем, не прибегая к внешней помощи московского монарха. Православные интеллектуалы, принимавшие участие в полемике и борьбе за права, в первой половине XVII века старались демонстрировать лояльность королевской власти для подтверждения своей благонадежности, ведь католики относились к ним с подозрением. Они конструировали и использовали «свое прошлое», вплетая в создаваемый нарратив важные, по их мнению, события. Для полемистов литовские и польские правители такие же свои, как и древнерусские князья.

Конечно, с одной стороны, православные интеллектуалы преследовали свои цели, поэтому им необходимо было убедить поляков в своей лояльности. И было бы с их стороны опрометчиво создавать в литературе негативный образ «своего» короля, ведь от него зависела их судьба, поэтому традиционно виновниками бед выступали скорее католики, а потом униаты. Мы рассмотрели образ власти, созданный в полемической литературной традиции, что не исключает и другие, возможно в некотором отношении противоположные, взгляды на «своего» правителя среди шляхты, простого «руского» народа или казачества. Можно допустить, что в некоторых случаях полемисты целенаправленно осторожно высказывались о власти для достижения своих целей. С другой стороны, полностью опровергать искренность намерений и утверждений православных церковных деятелей было бы также неправильно. В противном случае мы бы чаще фиксировали интерес иерархов к Московскому царству как к «своей» близкой общности, к православному монарху, а также куда активнее должны были быть контакты с

$$
-1588-
$$


Москвой. Однако подобные тенденции можно проследить не на рубеже XVI-XVII вв., а уже позднее, когда борьба происходила не только на листах бумаги, но и на полях сражений.

\section{6. Благодарности}

Исследование выполнено при финансовой поддержке гранта Российского научного фонда («Национальная идентичность в имперской политике памяти: история Великого княжества Литовского и Польско-Литовского государства в историографии и общественной мысли XIX-XX вв.» Проект РНФ № 19-18-00073).

\section{Литература}

АЗР, 1851 - Акты, относящиеся к истории Западной России. Т. 4. СПб.: В типографии Эдуарда Прана, $1851.584 \mathrm{c.}$

Антиграфи, 1903 - Антиграфи // Русская историческая библиотека. Т. 19. Кн. 3. СПб.: Сенатская типография, 1903. С. 593-668.

Апокрисис, 1882 - Апокрисис // Русская историческая библиотека, издаваемая Археографической комиссией. Т. 7. СПб.: Типография А.М. Котомина и Ко, у Обуховского моста, по Фонтанке, 93, 1882. С. 520-928.

АЮЗР, 1887 - Архив Юго-Западной России, издаваемый временной комиссией для разбора древних актов, состоящей при Киевском, Подольском и Волынском генерал-губернаторе. Т. 7. Ч. 1. Киев: Типография Г.Т. Корчак-Новицкого, Михайловская улица, собств. дом, 1887. 800 с.

АЮЗР, 1914 - Архив Юго-Западной России, издаваемый временной комиссией для разбора древних актов, состоящей при Киевском, Подольском и Волынском генерал-губернаторе. Т. 8. Ч. 1. Киев: Лито-типогр. Акц. Об. Н.Т. Корчак-Новицкого, 1914. 798 с.

Бантыш-Каменский, 1830 - Бантыш-Каменский Н.Н. История Малой России. Ч. 1-3. М.: В типографии Семена Селиванского. 1830.

Барсук, 2014 - Барсук E.E. Этноконфессиональные отношения на белорусских и украинских землях в Речи Посполитой: историографический обзор // Современная научная мысль. 2014. № 6. C. $12-20$.

Білецький, 1963 - Білецький О.І. Письменник і епоха. К.: Держлітвидав, 1963. 538 с.

Білецький, 1965 - Білецький О.І. Зібрання праць: У 5-ти т. Т. 1. К.: Наукова думка, 1965. 527 с.

Воронин, 2019 - Воронин В.A. Витовт - герой Литвы, Ольгерд - герой Руси // «Места памяти» Руси конца XV - середины XVIII в. / Отв. ред. А.В. Доронин. М.: Политическая энциклопедия, 2019. C. 88-102.

Грушевський, 1995 - Грушевський М.С. Історія української літератури: В 6 т. 9 кн. Т. 5. Кн. 2 / упоряд. О.В. Дідух; приміт. С. К. Росовецького. К.: Либідь, 1995. 352 с.

Грушевський, 1996 - Грушевський М.С. Історія української літератури: В 6 т. 9 кн. Т. 6. Кн. 1. / упоряд. С. К. Росовецький. Київ: Либідь, 1996. 262 с.

Дернович, 2018 - Дернович О.И. Конструируя «Другую Русь»: Образы «Руси» в историописании Великого княжества Литовского XVI-XVII веков // Россия и Беларусь: история и культура в прошлом и в настоящем // Материалы Международной научной конференции «Россиеведение и белорусоведение в XXI веке: традиционные и новые тенденции в научных исследованиях» (Смоленск, 11-12 октября 2018 г.) / Под ред. Е.В. Кодина. Вып. 4. Смоленск: Изд-во СмолГУ. 2018. С. 74-89.

Диариуш, 1878 - Диариуш // Русская историческая библиотека, издаваемая Археографической комиссией. Т. 4. СПб.: Типография и Хромолитография А. Траншеля, Стремянная, № 12, 1878. С. 35-88.

Дмитриев, 2008 - Дмитриев М.В. О формировании дискурсов общерусского самосознания в украинско-белорусской культуре конца XVI-XVII вв. // Украина и Россия: история и образ истории. М.: [Б. и.], 2008.

Доронин, 2017 - Древняя Русь после Древней Руси. Дискурс восточнославянского (не)единства / Отв. ред. А.В. Доронин. М.: Политическая энциклопедия, 2017. 399 с.

Доронин, 2018 - Нарративы Руси конца XV - середины XVIII в.: в поисках своей истории / Отв. ред. А.В. Доронин. М.: Политическая энциклопедия, 2018. 430 с.

Доронин, 2019 - «Места памяти» Руси конца XV - середины XVIII в. / Отв. ред. А.В. Доронин. М.: Политическая энциклопедия, 2019. 518 с.

Доронин, 2020 - Религия и Русь, XV-XVIII вв. / Отв. сост. А.В. Доронин. М.: РОССПЭН, 2020. 447 с. Еремин, 1946 - Еремин И.П. Борьба за национальную независимость в украинской литературе XVI-XVII вв. // Труды юбилейной сессии: Секция филологических наук. Л.: Изд. Лен. гос. университета, 1946. С. 226-244.

Житецкий, 1890 - Житецкий И.П. Литературная деятельность Иоанна Вишенского. К.: Тип. Г.Т. Корчак-Новицкого, 1890.50 с.

Жукович, 1901 - Жукович П.Н. Сеймовая борьба православного западнорусского дворянства с церковной унией (до 1609 г.). СПб.: Тип. Гл. упр. уделов, 1901. 610 с. 
Завитневич, 1883 - Завитневич В.З. Палинодия Захарии Копыстенского и ее место в истории западнорусской полемики XVI и XVII вв. Варшава: Ип. Варшавскаго учебнаго округа, 1883. 492 с.

Казанье святого Кирилла, 1906 - Казанье святого Кирилла // Памятки полемічного письменства кінця XVI і поч. XVII в. Т. 1. Львів: Археогр. коміс. Наук. т-ва ім. Шевченка, 1906. С. 31-200.

Ключ Царства, 1887 - Ключ царства небесного // Архив Юго-Западной России. Т. 7. Ч. 1. Киев: Типография Г.Т. Корчак-Новицкого, Михайловская улица, собств. дом, 1887. С. 232-265.

Костомаров, 1888 - Костомаров Н.И. Русская история в жизнеописаниях ее главнейших деятелей. Т. 1. СПб.: Типография М.М. Стасюлевича, Вас. Остр., 2 л., 7, 1888. 728 с.

Коялович, 1863 - Коялович М.О. Люблинская уния или последнее соединение литовского княжества с Польским королевством на Люблинском сейме в 1569 году. СПб.: Газ. «Рус. инвалид», 1863. $87 \mathrm{c}$.

Коялович, 1864 - Коялович М.О. Лекции по истории Западной России. М.: В типографии Бахметева, 1864. 394 с.

Миллер, 2000 - Миллер А.И. «Украинский вопрос» в политике властей и русском общественном мнении (вторая половина XIX века). СПб.: Алетейя, 200о. 260 с.

Неменский, 2013 - Неменский О.Б. Русско-польские войны в восприятии православных и униатских полемистов в Речи Посполитой первой половины XVII века // Славянский мир в третьем тысячелетии. К 1150-летию славянской письменности. Кн. 1. М.: Институт славяноведения РАН, 2013. C. $287-296$.

Палинодия, 1878 - Палинодия // Русская историческая библиотека, издаваемая Археографической комиссией. Т. 4. СПб.: Типография и Хромолитография А. Траншеля, Стремянная, № 12,1878 . C. $167-610$.

Перестрога, 1851 - Перестрога // Акты, относящиеся к истории Западной России. Т. 4. СПб.: В типографии Эдуарда Прана, 1851. С. 203-236.

Перетц, 1962 - Перетц В.Н. Исследования и материалы по истории старинной украинской литературы XVI-XVII вв. М.-Л., 1962. 255 с.

Послание до латин, 1903 - Послание до латин из их же книг // Русская историческая библиотека. Т. 19. Кн. 3. СПб.: Сенатская типография, 1903. С. 580-592.

Протестация, 1909 - Протестация митрополита Иова Борецкого и других западнорусских иерархов / Ком. П.Н. Жукович. СПб.: Тип. Академии наук, 1909. 19 с.

РИБ, 1878 - Русская историческая библиотека, издаваемая Археографической комиссией. Т. 4.

СПб.: Типография и Хромолитография А. Траншеля, Стремянная, № 12, 1878. 882 c.

РИБ, 1882 - Русская историческая библиотека. Т. 7. Кн. 2. СПб.: Тип. А.М. Котомина и Ко, 1882. $930 \mathrm{c}$.

РИБ, 1903 - Русская историческая библиотека. Т. 19. Кн. 3. СПб.: Сенатская типография, 1903. 872 с.

Русина, 2008 - Русина E.B. Проблемы политической лояльности православного населения Великого княжества Литовского в XIV-XVI ст. // «Украина и Россия: история и образ истории». М.: [Б. и.], 2008.

Савченко, 2007 - Савченко С.В. Полемічна література XVI-XVII ст. в українській історіографії // Украӥнський історичний журнал. 2007. № 5. С. 158-174.

Скабаланович, 1873 - Скабаланович Н.А. Об Апокрисисе Христофора Филалета. СПб.: Тип.

К.В. Трубникова, 1873. 225 с.

Словарь исторический, $1827 a$ - Словарь исторический о бывших в России писателях духовного

чина греко-российской церкви. Т. 1. СПб.: В типографии Ивана Глазунова, 1827. $351 \mathrm{c.}$

Словарь исторический, $1827 \mathrm{~b}$ - Словарь исторический о бывших в России писателях духовного чина греко-российской церкви. Т. 2. СПб.: В типографии Ивана Глазунова и его иждивением, 1827. 418 с.

Студинський, 1906 - Памятки украінсько-руськоі мови і літератури. Т. 5: Памятки полэмічного письменства кінця XVI і поч. XVII в. / вид. К. Студинський. Львів: Коміс. Археограф. Наук. Тов-ва ім. Шевченка, 1906. 314 с.

Тренос, 1995 - Тренос, тобто Плач... (фрагменти) // Українські гуманісти епохи Відродження. Антологія. У 2-х ч. Ч. 2. Київ: Наук. Думка; Основи, 1995. С. 284-332.

Frick, 1987 - Collected Works of Meletij Smotryc' kyj / intr. by D.A. Frick. Vol. 1, Cambridge, Mass.: Harvard Ukr. research inst., $1987.860 \mathrm{p}$.

Frick, 2005 - Rus' Restored. Selected Writings of Meletij Smotryc'kyj, 1610-1630. Transl. by D.A. Frick. Cambridge, MA: Harvard University Press, 2005, 810 p.

Hodana, 2008 - Hodana, T. (2008). Między królem a carem. Moskwa w oczach prawosławnych Rusinów - obywateli Pzeczypospolitej (na podstawie piśmiennictwa końca XVI - połowy XVII stulecia). Kraków: "Scriptum". 262 p.

Lev Krevza's..., 1995 - Lev Krevza's A defense of church unity and Zaharija Kopystens'kyj's Palinodia. Texts / transl. with a forew. by Bohdan Struminski / ed. by R. Koropeckyi, D.R. Miller, W.R. Veder. Harvard: Harvard Ukr. research inst., 1995.911 p.

Obrona Verificaciey, 1887 - Obrona Verificaciey // Архив Юго-Западной России. Т. 7. Ч. 1. Киев: Типография Г. Т. Корчак-Новицкого, Михайловская улица, собств. дом, 1887. С. 345-442. 
Synopsis, 1887 - Synopsis // Архив Юго-Западной России. Т. 7. Ч. 1. Киев: Типография Г.Т. Корчак-Новицкого, Михайловская улица, собств. дом, 1887. С. 533-576.

\section{References}

Antigrafi, 1903 - Antigrafi. Russkaya istoricheskaya biblioteka. T. 19. Kn. 3. SPb.: Senatskaya tipografiya, 1903. Pp. 593-668. [in old Polish]

Apokrisis, 1882 - Apokrisis. Russkaya istoricheskaya biblioteka, izdavaemaya Arkheograficheskoi komissiei. T.7. SPb.: Tipografiya A. M. Kotomina i Ko, u Obukhovskogo mosta, po Fontanke, 93, 1882. Pp. 520-928. [in old Ukrainian]

AYuZR, 1887 - Arkhiv Yugo-Zapadnoi Rossii, izdavaemyi vremennoi komissiei dlya razbora drevnikh aktov, sostoyashchei pri Kievskom, Podol'skom i Volynskom general-gubernatore [Archive of South-Western Russia, published by the temporary commission for the study of ancient acts, consisting of the Kiev, Podolsk and Volyn Governor-General]. T. 7. Ch. 1. Kiev: Tipografiya G. T. Korchak-Novitskogo, Mikhailovskaya ulitsa, sobstv. dom, 1887.800 p. [in Russian]

AYuZR, 1914 - Arkhiv Yugo-Zapadnoi Rossii, izdavaemyi vremennoi komissiei dlya razbora drevnikh aktov, sostoyashchei pri Kievskom, Podol'skom i Volynskom general-gubernatore [Archive of South-Western Russia, published by the temporary commission for the study of ancient acts, consisting of the Kiev, Podolsk and Volyn Governor-General]. T. 8. Ch. 1. Kiev: Ligo-tipogr. Akts. Ob. N.T. Korchak-Novitskogo, 1914. 798 p. [in Russian]

AZR, 1851 - Akty, otnosyashchiesya $\mathrm{k}$ istorii Zapadnoi Rossii [Acts relating to the history of Western Russia]. T. 4. SPb.: V tipografii Eduarda Prana, 1851. 584 p. [in Russian]

Bantysh-Kamenskii, 1830 - Bantysh-Kamenskii, N.N. (1830). Istoriya Maloi Rossii [The History of Little Russia]. Ch. 1-3. M.: v tipografii Semena Selivanskogo. [in Russian]

Barsuk, 2014 - Barsuk, E.E. (2014). Etnokonfessional'nye otnosheniya na belorusskikh i ukrainskikh zemlyakh v Rechi Pospolitoi: istoriograficheskii obzor [Ethno-confessional relations in the Belarusian and Ukrainian Lands in the Polish-Lithuanian Commonwealth: a historiographical review]. Sovremennaya nauchnaya mysl'. 6: 12-20. [in Russian]

Bilets'kii, 1963 - Bilets'kii, O.I. (1963). Pis'mennik i epokha [Writer and era]. Kiev: Derzhlitvidav. 538 p. [in Ukrainian]

Bilets'kii, 1965 - Bilets'kii, O.I. (1965). Zibrannya prats': U 5-ti t. [Collection of works: in 5 volumes]. T. 1. Kiev: Naukova dumka. 527 p. [in Ukrainian]

Dernovich, 2018 - Dernovich, O.I. (2018). Konstruiruya «Druguyu Rus'»: Obrazy «Rusi» v istoriopisanii Velikogo knyazhestva Litovskogo XVI-XVII vekov [Designing the "Other Rus": Images of "Rus" in the Historiography of the Grand Duchy of Lithuania of the 16th-17th centuries]. Rossiya $i$ Belarus': istoriya i kul'tura $v$ proshlom i $v$ nastoyashchem: materialy mezhdunarodnoi nauchnoi konferentsii «Rossievedenie $i$ belorusovedenie $v$ XXI veke: traditsionnye $i$ novye tendentsii $v$ nauchnykh issledovaniyakh» (Smolensk, 11-12 oktyabrya 2018 g.). Pod red. E.V. Kodina. Vyp. 4. Smolensk: SmolSU. Pp. 74-89. [in Russian]

Diariush, 1878 - Diariush. Russkaya istoricheskaya biblioteka, izdavaemaya Arkheograficheskoi komissiei. T. 4. SPb.: Tipografiya i Khromolitografiya A. Transhelya, Stremyannaya, №12, 1878. Pp. 35-88. [in old Ukrainian]

Dmitriev, 2008 - Dmitriev, M.V. (2008). O formirovanii diskursov obshcherusskogo samosoznaniya v ukrainsko-belorusskoi kul'ture kontsa XVI-XVII vv. [On the formation of discourses of the All-Russian selfconsciousness in the Ukrainian-Belarusian culture of the late 16th-17th centuries]. Ukraina i Rossiya: istoriya i obraz istorii. M.: [B. i.]. [in Russian]

Doronin, 2017 - Drevnyaya Rus' posle Drevnei Rusi. Diskurs vostochnoslavyanskogo (ne)edinstva [Old Rus after Old Rus. The Discourse of East Slavic (non-) Unity]. Otv. red. A. V. Doronin. M.: Politicheskaya entsiklopediya, 2017. 399 p. [in Russian]

Doronin, 2018 - Narrativy rusi kontsa XV - serediny XVIII v.: v poiskakh svoei istorii [Narratives of Rus of the late 15th - mid 18th century: in search of one's own history]. Otv. red. A. V. Doronin. M.: Politicheskaya entsiklopediya, 2018. 430 p. [in Russian]

Doronin, 2019 - «Mesta pamyati» rusi kontsa XV - serediny XVIII v. ["Places of memory" of Rus at the end of the 15th - the middle of the 18th centuries]. Otv. red. A. V. Doronin. M.: Politicheskaya entsiklopediya, 2019. 518 p. [in Russian]

Doronin, 2020 - Religiya i rus', XV-XVIII vv. [Religion and Russia, the 15th - 18th centuries]. Otv. sost. A. V. Doronin. M.: ROSSPEN, 2020. 447 p. [in Russian]

Eremin, 1946 - Eremin, I.P. (1946). Bor'ba za natsional'nuyu nezavisimost' v ukrainskoi literature XVI-XVII vv. [The Struggle for National Independence in Ukrainian Literature of the 16th-17th centuries]. Trudy yubileinoi sessii: Sektsiya filologicheskikh nauk. L.: Ed. Len. State University. Pp. 226-244. [in Russian]

Frick, 1987 - Collected Works of Meletij Smotryc'kyj / intr. by D.A. Frick. Vol. 1, Cambridge, Mass.: Harvard Ukr. research inst., $1987.860 \mathrm{p}$. 
Frick, 2005 - Rus' Restored. Selected Writings of Meletij Smotryc'kyj, 1610-1630. Transl. by D.A. Frick. Cambridge, MA: Harvard University Press, 2005, 810 p.

Grushevs'kii, 1995 - Grushevs'kii, M.C. (1995). Istoriya ukraïns'koï literaturi: V 6 t. 9 kn. [History of Ukrainian literature: in 6 volumes 9 books.]. T. 5. Kn. 2. Uporyad. O.V. Didukh; primit. S.K. Rosovets'kogo. Kiev: Libid'. 352 p. [in Ukrainian]

Grushevs'kii, 1996 - Grushevs'kii, M.C. (1996). Istoriya ukraïns'koï literaturi: V 6 t. 9 kn. [History of Ukrainian literature: in 6 volumes 9 books]. T. 6. Kn. 1. Uporyad. S.K. Rosovets'kii. Kiev: Libid'. 262 p. [in Ukrainian]

Hodana, 2008 - Hodana, T. (2008). Między królem a carem. Moskwa w oczach prawosławnych Rusinów - obywateli Pzeczypospolitej (na podstawie piśmiennictwa końca XVI - połowy XVII stulecia). Krakow: "Scriptum". 262 p. [in Polish]

Kazan'e svyatogo Kirilla, 1906 - Kazan'e svyatogo Kirilla. [The Legend of St. Cyril]. Pamyatki polemichnogo pis'menstva kintsya XVI i poch. XVII v. T. 1. L'viv: Arkheogr. komis. Nauk. t-va im. Shevchenka, 1906. Pp. 31-200. [in old Ukrainian and in old Polish]

Klyuch Tsarstva, 1887 - Klyuch tsarstva nebesnogo. [The Key of the Kingdom of Heaven]. Arkhiv Yugo-Zapadnoi Rossii. T. 7. Ch. 1. Kiev: Tipografiya G. T. Korchak-Novitskogo, Mikhailovskaya ulitsa, sobstv. dom, 1887. Pp. 232-265. [in old Ukrainian]

Kostomarov, 1888 - Kostomarov, N.I. (1888). Russkaya istoriya v zhizneopisaniyakh ee glavneishikh deyatelei. [Russian history in the biographies of its main figures] T. 1. SPb.: Tipografiya M. M. Stasyuevicha, Vas. Ostr., 2 l., 7. 728 p. [in Russian]

Koyalovich, 1863 - Koyalovich, M.O. (1863). Lyublinskaya uniya ili poslednee soedinenie litovskogo knyazhestva s Pol'skim korolevstvom na Lyublinskom seime v 1569 godu. [Union of Lublin or the last union of the Lithuanian principality with the Kingdom of Poland at the Lublin Diet in 1569]. SPb.: Gaz. "Rus. invalid». 87 p. [in Russian]

Koyalovich, 1864 - Koyalovich, M.O. (1864). Lektsii po istorii Zapadnoi Rossii [Lectures on the history of Western Russia]. M.: v tipografii Bakhmeteva, 394 p. [in Russian]

Lev Krevza's..., 1995 - Lev Krevza's A defense of church unity and Zaharija Kopystens'kyj's Palinodia. Texts transl. with a forew. by Bohdan Struminski. Ed. by R. Koropeckyi, D.R. Miller, W.R.Veder. Harvard: Harvard Ukr. research inst., 1995. 911 p.

Miller, 2000 - Miller, A.I. (2000). «Ukrainskii vopros» v politike vlastei i russkom obshchestvennom mnenii (vtoraya polovina XIX veka). [The "Ukrainian problem" in the policy of the authorities and Russian public opinion (the second half of the 19th century)]. SPb.: Aleteiya. 260 p. [in Russian]

Nemenskii, 2013 - Nemenskii, O.B. (2013). Russko-pol'skie voiny v vospriyatii pravoslavnykh i uniatskikh polemistov v Rechi Pospolitoi pervoi poloviny XVII veka [Russian-Polish Wars in the Perception of Orthodox and Uniate Polemicists in the Polish-Lithuanian Commonwealth of the first half of the 17th century]. Slavyanskii mir v tret'em tysyacheletii. K 1150-letiyu slavyanskoi pis'mennosti. Kn. 1. M.: Institute of Slavic Studies of the RAS. Pp. 287-296. [in Russian]

Palinodiya, 1878 - Palinodiya. Russkaya istoricheskaya biblioteka, izdavaemaya Arkheograficheskoi komissiei. T. 4. SPb.: Tipografiya i Khromolitografiya A. Transhelya, Stremyannaya, №12, 1878. Pp. 167-610. [in old Ukrainian]

Perestroga, 1851 - Perestroga. Akty, otnosyashchiesya k istorii Zapadnoi Rossii. T. 4. SPb.: V tipografii Eduarda Prana, 1851. Pp. 203-236. [in old Ukrainian]

Peretts, 1962 - Peretts, V.N. (1962). Issledovaniya i materialy po istorii starinnoi ukrainskoi literatury XVI-XVII vv. [Research and materials on the history of old Ukrainian literature of the 16th -17 th centuries] M.; L. 255 p. [in Russian]

Poslanie do latin, 1903 - Poslanie do latin iz ikh zhe knig. [A message to the Latins from their own books]. Russkaya istoricheskaya biblioteka. T. 19. Kn. 3. SPb.: Senatskaya tipografiya, 1903. Pp. 580-592. [in old Ukrainian]

Protestatsiya, 1909 - Protestatsiya mitropolita Iova Boretskogo i drugikh zapadnorusskikh ierarkhov.

[Protest of Metropolitan Iova Boretsky and other Western Russian hierarchs]. Kom. P. N. Zhukovich. SPb.: print. at the Academy of Sciences, 1909. 19 p. [in Russian]

RIB, 1878 - Russkaya istoricheskaya biblioteka, izdavaemaya Arkheograficheskoi komissiei [Russian

Historical Library, published by the Archaeographic Commission] T.4. SPb.: Tipografiya i Khromolitografiya A. Transhelya, Stremyannaya, №12, 1878. 882 p. [in Russian]

RIB, 1882 - Russkaya istoricheskaya biblioteka [Russian Historical Library]. T. 7. Kn. 2. SPb.: Tip.

A.M. Kotomina i Ko, 1882. 930 p. [in Russian]

RIB, 1903 - Russkaya istoricheskaya biblioteka. [Russian Historical Library]. T. 19. Kn. 3. SPb.: Senatskaya tipografiya, $1903.872 \mathrm{p}$. [in Russian]

Rusina, 2008 - Rusina, E.V. (2008). Problemy politicheskoi loyal'nosti pravoslavnogo naseleniya Velikogo knyazhestva Litovskogo v XIV-XVI st. [Problems of political loyalty of the Orthodox population of the Grand Duchy of Lithuania in the 14th - 16th centuries]. Ukraina i Rossiya: istoriya i obraz istorii. M.: [B. i.]. [in Russian] 
Savchenko, 2007 - Savchenko, S.V. (2007) Polemichna literatura XVI-XVII st. v ukrains'kii istoriografii. [Polemical literature of the 16th -17 th centuries in Ukrainian historiography]. Ukrainian Historical Journal. 5: 158-174. [in Ukrainian]

Skabalanovich, 1873 - Skabalanovich, N.A. (1873). Ob Apokrisise Khristofora Filaleta [On the Apokrisise of Christopher Philaletus]. SPb.: tip. K.V. Trubnikova. 225 p. [in Russian]

Slovar' istoricheskii, 1827a - Slovar' istoricheskii o byvshikh v Rossii pisatelyakh dukhovnogo china greko-rossiiskoi tserkvi. [The historical dictionary about the writers of the spiritual rank of the GreekRussian church who were in Russia]. T. 1. SPb.: v tipografii Ivana Glazunova, 1827. 351 p. [in Russian]

Slovar' istoricheskii, $1827 \mathrm{~b}$ - Slovar' istoricheskii o byvshikh v Rossii pisatelyakh dukhovnogo china greko-rossiiskoi tserkvi [The historical dictionary about the writers of the spiritual rank of the Greek-Russian church who were in Russia]. T. 2. SPb.: v tipografii Ivana Glazunova i ego izhdiveniem, 1827. 418 p. [in Russian]

Studins'kii, 1906 - Pamyatki ukrains'ko-rus'koi movi i literaturi. [Sights of Ukrainian-Russian language and literature]. T. 5: Pamyatki polemichnogo pis'menstva kintsya KhVI i poch. KhVII v. Vid. K. Studins'kii. L'viv: Komis. Arkheograf. Nauk. Tov-va im. Shevchenka, 1906. 314 p. [in Ukrainian]

Trenos, 1995 - Trenos, tobto Plach... (fragmenti). [Trenos or Lamentation... (fragments)]. Ukraïns'ki gumanisti epokhi Vidrodzhennya. Antologiya. U 2-kh ch. Ch. 2. K.: Nauk. Dumka; Osnovi, 1995. Pp. 284-332. [in Ukrainian]

Voronin, 2019 - Voronin, V.A. (2019). Vitovt - geroi Litvy, Ol'gerd - geroi Rusi [Vitovt is the hero of Lithuania, Olgerd is the hero of Rus]. "Mesta pamyati» rusi kontsa XV - serediny XVIII v. Otv. red. A.V. Doronin. M.: Politicheskaya entsiklopediya. Pp. 88-102. [in Russian]

Zavitnevich, 1883 - Zavitnevich, V.Z. (1883). Palinodiya Zakharii Kopystenskogo i ee mesto v istorii zapadno-russkoi polemiki XVI I XVII vv. [Palinode of Zachary Kopystensky and its place in the history of Western Russian polemics in the 16th and 17th centuries]. Warsaw: ip. Varshavskago uchebnago okruga. 492 p. [in Russian]

Zhitetskii, 1890 - Zhitetskii, I.P. (1890). Literaturnaya deyatel'nost' Ioanna Vishenskogo [Literary activity of IoannaVishensky]. K.: tip. G.T. Korchak-Novitskogo. 50 p. [in Russian]

Zhukovich, 1901 - Zhukovich, P.N. (1901). Seimovaya bor'ba pravoslavnogo zapadnorusskogo dvoryanstva s tserkovnoi uniei (do 1609 g.) [Diet struggle of the Orthodox Western Russian nobility with the curch union (until 1609)]. SPb.: tip. Gl. upr. udelov. 610 p. [in Russian]

\section{Польско-литовская власть и православная Русь в трудах полемистов конца XVI - первой трети XVII вв.}

Юлия Алексеевна Чупрына а , *

a Санкт-Петербургский государственный университет, Российская Федерация

Аннотация. В данном исследовании рассматриваются особенности конструирования образа польско-литовской власти в контексте религиозной полемики рубежа XVI-XVII вв. Результатом дискуссии православных и униатов в Речи Посполитой стала полемическая литература, которая создавалась в контексте борьбы православия за свои права и свободы. Полемическая литература как исторический источник в XIX-XX века рассматривалась через призму национального проекта или уже существующего национального нарратива. Исследуя особенности взаимодействия Украины и России, историки находили в полемике XVII века подтверждения для обоснования угнетения народа, самобытной культуры и национальной борьбы. В современной историографии предлагаются новые ракурсы, сконцентрированные на интеллектуальной истории и memory studies. Наибольший интерес в этой связи представляет историческое мировоззрение человека XVII века.

В центре внимания находятся взгляды православных полемистов как представителей «руского» народа Речи Посполитой на историю правления литовских князей и польских королей. В условиях принятия Брестской унии усилился интерес к «своему» прошлому, правовому положению, лояльности к королю, усложнилось восприятие польских и литовских правителей. Стремясь к легализации православия, церковные деятели актуализировали исторические образы князей и королей, представляя их дарителями и гарантами прав и свобод Руси. Борцов за православие не отталкивало то, что король относился к католической религии, они скорее выступали за равенство греческой и римской веры. Обоснование равенства мы находим в апелляции к славному прошлому, к истории присоединения земель Руси к Литве, Люблинской унии, даровании и подтверждении привилеев.

Ключевые слова: православные полемисты, образ власти, Речь Посполитая, Русь, Брестская уния.

\footnotetext{
${ }^{*}$ Корреспондирующий автор

Адреса электронной почты: chupryna.yulya@mail.ru (Ю.А. Чупрына) 